\title{
The materialization of the Buen Vivir and the Rights of Nature: Rhetoric and Realities of Guayaquil Ecológico urban regeneration project
}

\author{
María Fernanda Ordóñez ${ }^{*}$, Kelly Shannon and Viviana d'Auria
}

\begin{abstract}
In 2008, Ecuador became the first country in the world to declare nature as a subject of rights based on the 'Buen Vivir' (Good Living) philosophy which is premised on an indigenous principle that envisions a world where humans are part-and-parcel of a larger natural and social environment. Although Ecuador's constitution is groundbreaking from a legal standpoint, the question arises of how the rights of nature is spatially manifested beyond the designation of protected areas? To shed light on such interrogation, this article, based on qualitative research, focuses on the linear park component of the mega-project Guayaquil Ecológico heralded as a first materialization which champions the "Rights of Nature" under the vision of the Buen Vivir. It unravels the contested rhetoric and realities of the Guayaquil Ecológico linear park in a critical review of the as-built project in relation to the larger objectives of Buen Vivir. The Guayaquil Ecologico linear park promised to simultaneously upgrade both social and environmental dimensions. However, it did not fully address the complexity of Guayaquil's socio-ecological context and some of the structural injustices of the estuarine territory. Buen Vivir was rhetorically mobilised to implement a project where aesthetic dimensions dominated, further perpetuating socio-ecological vulnerabilities through relocation and evictions. Furthermore, its implementation was dependent on a specific political moment, leaving it in a state of abandonment and neglect. The Buen Vivir philosophy — as a decolonial stance that challenges western forms of development — can offer a fundamental base to question current modes of territorial occupation based on extractivist planning and design strategies. It holds significant potential to serve as base to re-think the relationship between forms of settlement, natural dynamics, and worldviews.
\end{abstract}

Keywords: Urban design, Urban planning, Rights of nature, Green infrastructure, Guayaquil, Global south

\section{Background}

At the beginning of this century, atmospheric chemist Paul Crutzen and limnologist Eugene Stoermer suggested we are currently living in the Anthropocene (Crutzen and Stoermer 1999), a human-dominated geological epoch, where human activities are the driving force of environmental change. Twenty two years later,

\footnotetext{
*Correspondence: mariafernanda.ordoneztapia@kuleuven.be Department of Architecture, Faculty of Engineering Science, KU Leuven, Kasteelpark Arenberg 51-Box 2431, 3001 Leuven, Belgium
}

the latest report from the Intergovernmental Panel on Climate Change (2021) reaffirms that 'human influence on the climate system is now an established fact' (IPCC 2021:51) and that 'many changes due to past and future greenhouse gas emissions are irreversible for centuries to millennia, especially changes in the ocean, ice sheets and global sea level' (IPCC 2021:28) consequently, high expectations are placed on the upcoming Conference of the Parties (COP26) when countries update their plans for reducing emission to hold temperature rise to 1.5 degrees although, so far, the move from declarations and 
protocols to concrete actions is infinitely more challenging. For many, including scientists, scholars, writers, religious leaders, etc., we are now at a critical tipping point (Childers et al. 2015; Klein 2014; Kolbert 2014; Pope Francis 2015; Purdy 2015; Wilson 2016) stating that 'If social justice was the axis of social uprisings in the twentieth century, environmental conflict is the one that concentrates most of the attention and mobilization at a global scale so far in the twenty-first century' (Acosta 2008:1).

Early on, in the field of planning and urbanism, a number of scholarly works by Western scholars reflected environmental concerns, particularly those of Ebenezer Howard's Garden City movement (1898) and Ian McHarg, who pioneered the concept of environmental planning in his book Design with Nature (1969). In the same manner, ever-growing efforts to 'fix' the socioenvironmental consequences of the Anthropocene have taken place through a cascade of international agreements and summits that, in principle, commit to a more sustainable way of living including the widely known Sustainable Development Goals (SDG) set by the United Nations in 2015 as part of its 2030 Agenda. However, although globally accepted, critics point to the SDG failure to question fundamental elements of western societies such as modernity, capitalism and anthropocentrism (Hidalgo-Capitán et al. 2019:8) which are the cause of the current multidimensional crises therefore, we are not entering a process of change of paradigm, but rather an adjustment of an exhausted model looking for new ways of recycling and efficiency (Pengue 2017:17) while maintaining a capitalistic economic model that further sustains dualistic positions, market/economy, science and reality, the world as we know it, a 'Unique World' (Escobar 2017:112) where the move from declarations and protocols to concrete actions is infinitely more challenging and, 'compromised summit declarations do not have a forceful impact'(Shannon 2017:50) in this sense, is worth noting that, 'growing threats to bio-diversity at a global scale have prompted calls to extend legal rights to nature as an elaboration of existing humanist doctrines'(Gandy 2018:104).

In 2008, Ecuador became the first country in the world to enshrine the Rights of Mother Nature in its constitution '(...) Such a groundbreaking constitutional construction is a historical and potentially transcendent step towards recognising the inherent ecological integrity and value of nature as a subject of law and a bearer of rights'(Kotzé and Villavicencio Calzadilla 2017:404).The fundamental point of departure for this legal recognition, however, is the Andean cosmovision of Sumak Kawsay or Buen Vivir (Good Living) which envisions humans as an integral part of nature. The 2008 constitution mandated the inclusion of spatial planning policy as a state instrument to achieve the Buen Vivir following the 12 objectives of the Buen Vivir National Plan (BVNP) which is the macro policy plan for the country and the foundation for the development of local policies. In this sense, territorial planning recognises and enforces nature's rights and guarantees biodiversity conservation through the National System of Protected Areas (NSPA). Supported by the biocentric constitution and understanding the benefits of green infrastructure as a strategic planning approach that tackles environmental issues while addressing ecological preservation as well as societal wellbeing (Benedict and McMahon 2000; Peters et al. 2010) the mega-project 'Generation and Restoration of Green Areas for the city of Guayaquil: Guayaquil Ecológico' was implemented in 2010 as part of the NSPA. As a first attempt to materialise the Buen Vivir vision through three different components, its overall aim was to upgrade the contemporary social and environmental conditions of Guayaquil, ultimately proving to be a complex task.

This paper is grounded in qualitative research and intends to provide a critical review of the linear park component of the project 'Generation and Restoration of Green Areas for the city of Guayaquil: Guayaquil Ecológico.' conceived under the Buen Vivir vision. First, a brief introduction based on relevant scholarship of the Buen Vivir philosophy is provided to understand how recognising the Rights of Nature is inherent to an Andean cosmovision. The case study is briefly introduced by understanding the city of Guayaquil as a site that is characterised by high biodiversity and social inequality. This is followed by a critical review of the linear park component of Guayaquil Ecologico in relation to the Buen Vivir objectives. Finally, it will highlight the promises and challenges of the implementation of Buen Vivir philosophy and Rights of Nature in the field of urbanism and planning as a basis to re-think urbanisation in relation to nature and push for a paradigmatic shift in the field.

\section{The re-emergence of Buen Vivir}

As a region fundamentally (re)shaped by colonisation, the foundation of the current socio-environmental circumstances is largely the result of imposed foreign ideas of "development" that started in the fifteenth century with the European conquest. The colonial era initiated an approach where Latin America's nature was tamed and commodified; it became an entity to be domesticated and exported (Acosta 2009; Miller 2007) and -in the name of progress and development-Latin American ecologies have been subjected to a plethora of extractive activities that have endured the serious social and ecological 
destruction caused by mega-mining or the exploitation of hydrocarbons (Acosta 2015). While Latin America is home to an estimated $40 \%$ of the world's biodiversity and to six out of seventeen "mega-diverse" countries (OECD 2018:14) it has, at the same time, the world's most inequitable distribution of wealth, land and income (OXFAM International 2015:6) thus, 'the struggle for nature has spontaneously attached itself to the struggle of economic and social justice. Many fights are as much about access to natural resources-clean water, fertile land, forest resources-as they are about saving them' (Miller 2007:215). In the past decade, the region underwent a 'process of political emancipation and decolonisation of knowledge that has subjected their cultures and degraded their environments, to reconstruct their own path towards sustainability' (Leff 2012:449). Ultimately, the combination of ecological mega-diversity, wealthinequality, a strong colonial history and a change in the political landscape, gave way to the re-emergence of the Buen Vivir (Good Living) philosophy questioning the imposed and inherited Western notions of development and progress.

Although this concept is concretely expressed in the Bolivian Law of Mother Earth (2010) and Ecuador's constitution of 2008, the Buen Vivir philosophy -and therefore the rights of Nature - is part of a vision of the world shared by many others such as the Muntu and Ubuntu in Africa, or the Svadeshi, Swaraj and Apargrama in India, that embraces diverse and multiple knowledges, realities and perspectives. A'Pluriverse (...) where the perseverance of non-dualist philosophies, reflect a deeply relational understanding of life' (Escobar 2016:22) Alberto Acosta, chairman of the 2008 constituent assembly and driving force behind the Yasuni-ITT initivative-, ${ }^{1}$ states that these different notions are all part of a long quest for life alternatives forged in the heat of humanity's struggles for emancipation and life (Acosta 2015:301). Eduardo Gudynas, one of the most influential thinkers in the region on development and the Buen Vivir, explains that it (the Buen Vivir) is a plural concept with two main entry points. On the one hand, it includes critical reactions to classical Western development theory. On the other hand, it refers to alternatives to development emerging from indigenous traditions, and in this sense the concept explores possibilities beyond the modern Eurocentric tradition' (Gudynas 2011a:441). He elaborates further, the 'Buen Vivir as an alternative for development must be based on a new environmental ethic

\footnotetext{
${ }^{1}$ An offer by Ecuador to fight climate change by forgoing oil exploitation and production in a large tract of untouched rainforest in the Ecuadorian Amazon. The project ultimately failed.
}

that recognises the intrinsic values in nature'(Gudynas 2011c:231). By recognising the Rights of Nature and its intrinsic values, the Ecuadorian Constitution-based on the Buen Vivir-moved from an anthropocentric view to a biocentric position representing a super-strong sustainability stance that, as Gudynas explains, defends a plural valuation of nature that considers ecological, aesthetic, religious, and cultural aspects, and advocates for the protection of ecosystems and all lifeforms regardless of their economic value. He adds, 'these values are inherent to live-species and ecosystems, independent from human utility or appreciation. This is the traditional biocentric posture. Here the technical solutions are important but insufficient to deal with these multiple valuations, therefore it is essential to count with political scenarios. While weak-sustainability could be resolved in a technocratic manner, super-strong sustainability is always a political discussion'(Gudynas 2011b:85). In this context, the declaration of the Rights of Nature comes as an intrinsic aspect of the Buen Vivir. Chapter Seven of the Constitution in the Rights of Nature section in articles 71 to 74 read:

'Article 71 . Nature, or Paccha Mama, where life
is reproduced and occurs, has the right to integral
respect for its existence and for the maintenance
and regeneration of its life cycles, structure, func-
tions and evolutionary processes. Article 72 . Nature
has the right to be restored. This restoration shall be
apart from the obligation of the State and natural
persons or legal entities to compensate individuals
and communities that depend on affected natural
systems. Article 73. The State shall apply preven-
tive and restrictive measures on activities that might
lead to the extinction of species, the destruction of
ecosystems and the permanent alteration of natu-
ral cycles. Article 74 . Persons, communities, peoples,
and nations shall have the right to benefit from the
environment and the natural wealth enabling them
to enjoy the good way of living.'

In territorial and regional planning, the designation of protected areas is the most evident spatial manifestation of the Rights of Nature. Ecuador is the second country in Latin America with the largest percentage (33.26\%) of protected territory (MAE 2016:4). Although Ecuador's constitution is groundbreaking and 'provides an example of how an abstract ethical acknowledgement of nature's rights could manifest concretely in the legal sphere (Kotzé and Villavicencio Calzadilla 2017:404)'the question that arises is, how can these rights be spatially manifested into urban and town planning, in order to 'build a new form of public coexistence, in diversity and in harmony with nature, to achieve the Good Living, the Sumak 
Kawsay'? as stated in the preamble of the Constitutional text.

To date, most literature and scholarship on the Buen Vivir has focused on policy implementation and legal issues (Calisto Friant and Langmore 2015; Garcia Alvarez 2015; Kauffman and Martin 2018; Whittemore 2011) political implications, alternatives to mainstream development and its environmental aspects (Acosta 2015; Gudynas 2011a, 2011c), resource exploitation, neoextractivism and development challenges (Lalander 2014; Vandegrift, et al. 2017; Villalba-Eguiluz and Etxano 2017; Whittemore 2011). Literature relating urbanism and planning with the Buen Vivir vision is growing. It is primarily focused on possibilities for green infrastructure and policy implementation (Serra-Llobet and Hermida 2017). An increasing number of studies are based on empirical findings that-wholly or partly-involve the Buen Vivir (Peek, et al. 2018; Sanchez Gallegos 2017; Shebell and Moser 2019). In this sense, this article aims to contribute, through an empirical study, to nascent literature relating the Buen Vivir philosophy with planning and urbanism, and at the same time, add to the incipient body of knowledge on green infrastructure in the global south (Parker and de Baro 2019; Pauleit, et al. 2021) aligned with recent scholarship on unforeseen socio-spatial consequences of green-infrastructure implementation in Latin America (Anguelovski et al. 2018; Anguelovski et al. 2016).

\section{Case description}

\section{Guayaquil: city and nature contestation}

The Guayaquil Ecológico mega project sought to achieve social and environmental restoration in GuayaquilEcuador's main port, economic centre, and second most populous city (2,698,077 inhabitants). Located in the lower part of the Guayas Basin, in the largest estuarine ecosystem $(12,500 \mathrm{~km})$ on the Pacific coast of South America (Cucalon 1983 as cited in Twilley et al. 2001:245) the city stretches along the Guayas River embedded in an extremely fertile environment known as Guayas Ecosystem (GE) which represents $31 \%(87,347 \mathrm{~km} 2)$ of Ecuadorian territory and is made up of 24 related watersheds (including the Guayas Basin) and the Guayas River estuary. A large part of the country's production (79\%) and consequent economic development depends on activities taking place within the GE such as cattle raising, agriculture, aquaculture and fishing activities, amongst others (Montaño Armijos and Sanfeliu Montolio 2008:26). In fact, Ecuador has overtaken India in 2020 as the lead exporter of shrimp (FAO 2021b) and continues to be tha largest exporter of bananas globally (FAO 2021a).

Aside from the Guayas River, the Salado Estuary is the most important water feature in the city. Once a healthy ecology that served as a recreational area and a source of livelihood, it is today a highly polluted environment mainly due to direct wastewater discharge from industries and residencies, both, formal and informal. The environmental degradation of the Salado Estuary was triggered by the banana boom (1950-1960) which 'revolutionized the economy of the costal lowlands of Ecuador and its commercial capital, Guayaquil' (Parsons 1957:203) causing massive rural to urban migration of people looking for job opportunities. Newcomers, however-as a result of unjust and exclusionary urbanization practices - had no choice but to settle in the floodable lands to the southwest, in an area currently known as Suburbio (Rojas Mosquera 2020:153) in precarious conditions. Consequently, 'the political and ecological history of Guayaquil's urbanisation process will be written from the perspective of the need to urbanise and domesticate nature's water and the parallel necessity to push the ecological frontier outward as the city expands' (Swyngedouw 1997:312). Throughout the years, the sustained occupation of the Salado Estuary with precarious settlements and direct wastewater discharge has precipitated biodiversity loss, decreased fishing activities and waterway navigability, while increasing water-related illnesses, a permanent stench and poor landscape scenery in addition to being increasingly exposed to heavy metals, such as mercury and lead, present in the water and mud (MAE 2015:10). During the 1980s, the floodable lands of Suburbio became saturated and too deep to fill, forcing new migration waves to head north aided by the new road infrastructure. By $2000,67.59 \%$ of the city was self-built (Sanchez Gallegos 2015:49) and was in an extreme state of urban decay.

In 1992, the right-wing Social Cristiano political party got elected to rule the city-and would stay in power for the next 29 years-Guayaquil then entered a version of the City Beautiful movement where the goal was to imbue a local sense of pride and social order through urban regeneration interventions, where the Malecon 2000 (a waterfront design along the Guayas River in the city center) was its emblematic project. The waterfront typology was soon replicated in lower income areas as well: the Playita del Guasmo (2004) in the south, and Malecon del Salado (2006) in the Suburbio. However, critics point out the controlled and exclusionary social practices and 'social cleansing'(Allan Alegria 2010; Andrade 2006) in these projects that ended up being more detrimental to existing livelihoods than a genuine public space where formal-informal relationships can continue to unfold. In this context, in 2010, inspired by a strong desire of urban, social and ecological regeneration, the then-newly elected national government led by Rafael Correa, planned the mega-project 'Generation 
and Restoration of Green Areas for the city of Guayaquil: Guayaquil Ecológico' which was executed by the Ministry of Housing and Urban Development (from now on MIDUVI) and the Ministry of Environment (from now on MAE).

\section{'Generation and Restoration of Green Areas for the city of Guayaquil: Guayaquil Ecológico'}

The Guayaquil Ecologico mega-project was executed as a project having national priority ${ }^{2}$ supported by the National Secretary of Planning and Development (SENPLADES) and was part of the National System of Protected Areas (NSPA). It sought to integrate nature conservation and human occupation through a variety of components: Santay Island (4705 ha), a Ramasar wetland; Samanes Urban Park (54.96 ha), and a $42 \mathrm{~km}$ long linear park along the Salado Estuary. In 2015, the project's area of intervention was expanded to include the Gulf of Guayaquil and the city of Duran and was renamed 'Green Areas and Public Space Provision for the Guayas Province: Guayas Ecologico.' This article examines the most complex component of the Guayaquil Ecologico mega-project: the linear park. It was the government's first and only attempt to physically enforce the newly re-adopted indigenous cosmovision through an urban design project embedded in an extremely dense and vulnerable context, from both a social and environmental perspective. Conceived under the Buen Vivir vision and heralded as championing the rights of Nature, the project claimed to adhere to five (out of 12) objectives of the 2013-2017 Buen Vivir National Plan (MAE 2015:29).

Objective 2: 'To foster social and territorial equality, cohesion and integration with diversity'.

Objective 3: 'To improve the quality of life of the population'.

Objective 4: 'To strengthen citizen's capacities and potential';

Objective 7: 'To guarantee nature's rights and to promote a healthy and sustainable environment';

Objective 8: 'To consolidate a social and solidarity economic system.'

The MAE was in charge of solid waste management and environmental education of families, the process of cleaning contaminated waters and the planting of vegetation. The MIDUVI on the other hand, oversaw relocation of inhabitants and the construction of the linear park which started in 2010. In 2018 however, the new national government prioritized resource allocation to the public housing program, 'Casa para todos,' (House for everyone) over green infrastructure projects, and the Guayaquil

${ }^{2}$ SENPLADES document NO. RL2010-194.
Ecologico mega-project was put on hold. During this time, a total of $15.8 \mathrm{~km}$ out of $42 \mathrm{~km}$ were built corresponding to seven out of the eleven proposed phases. The future of the remaining $25.5 \mathrm{~km}$ of linear park for the last 4 phases remains uncertain (Figs. 1, 2).

\section{Methods}

A combination of qualitative research methods was used to evaluate the project's claims of social and environmental upgrading (MAE and MIDUVI 2013:30). A qualitative approach was pertinent as it allows for a 'holistic "big picture" perspective that integrates what people say and do within the context of larger social, economic physical, environmental, and political factors' (Gaber 2020:19).

The triangulation of data allows for cross-checking information to identify discrepancies (Pettigrew 1990:277) and this was accomplished through the inclusion of non-participant observation, semi-structured interviews and data analysis. Non-participant observation included windshield survey and site reconnaissance that allowed the visual examination of the area and the first-hand recording impressions at different scales (Gaber 2020:22) a method which 'produces rigor when it is combined with other methods'(Meyer 2001:339). Semi structured interviews were carried out as they offer more detailed answers (Gaber 2020:31) and can provide depth, subtlety, and personal feeling (Pettigrew 1990:277).

Data was collected during two extensive fieldwork trips that took place in 2018 and 2019, each for a period of two months. The interviews were conducted with different stakeholders who could provide in-depth, first -hand knowledge about the project, including the former Subsecretary (s) of Marine and Coastal Management (governmental entity with competence over the Salado Estuary) former Director (d) of the Guayaquil Ecologico Project, an architect (a) from the MIDUVI, a biologist (b) from the MAE, a local expert (le) with extensive knowledge in informal settlements and public policies and a group of 11 residents ( $r$ ) made up of six male and five females aged between 30 and 60. Nine of them have lived in the area for more than 25 years. The windshield survey and site reconnaissance took place in 4 out of 7 built phases (1, 4, 5 and 6). Finally, observation and interaction with residents primarily occurred in Phase 5-where the highest number (799 families) of relocations took place (MIDUVI 2015:23). In this sense, findings and conclusions pertain to this phase and should not be taken as a general rule for the overall project. Visits to the park occurred at different hours of the day, between 9 a.m. and 6 p.m. Data collection included a thorough analysis of official reports and documents such as: Ecuador's Constitution (2008), The Buen Vivir National Plan 2013-2017 (SENPLADES 


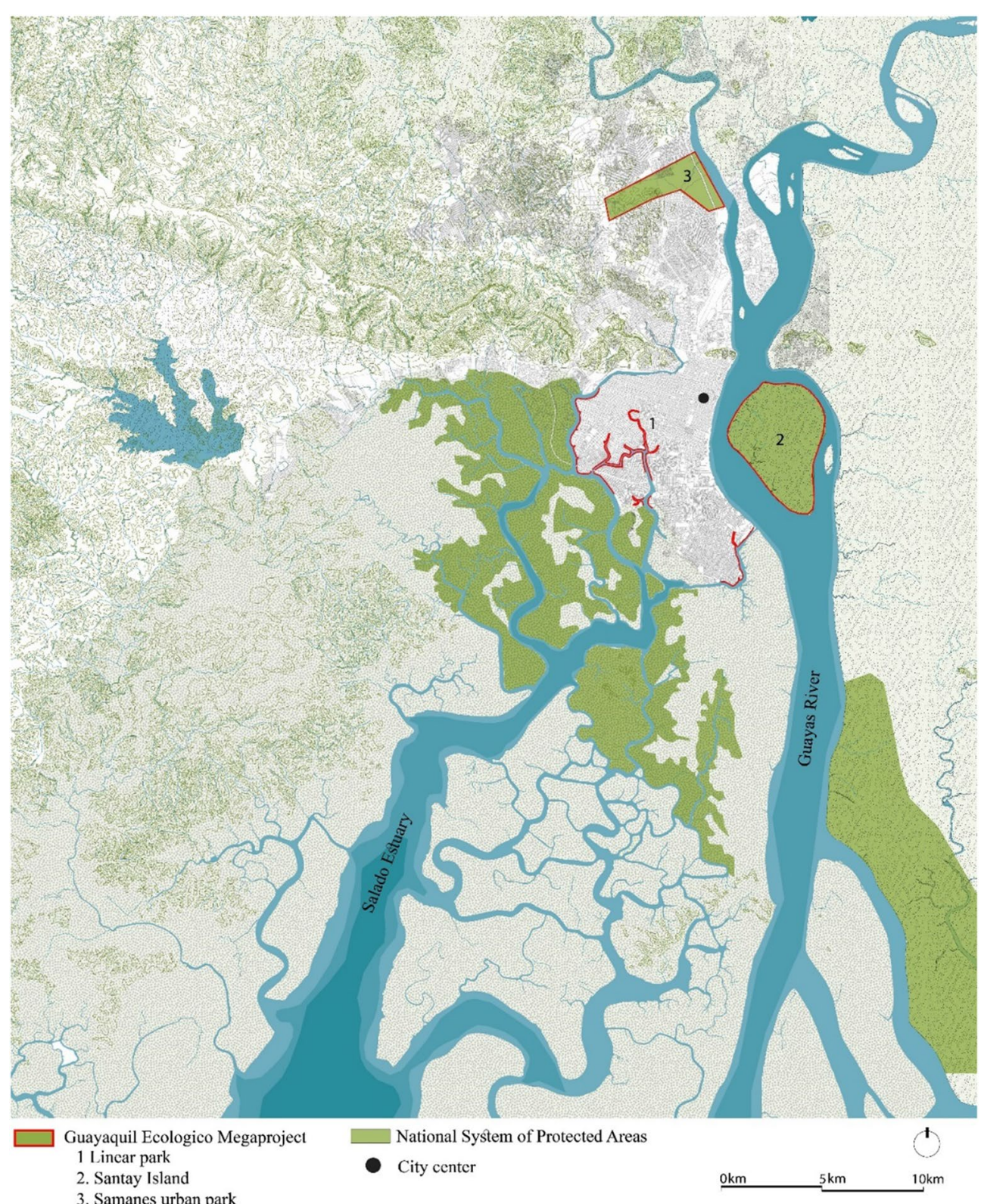

Fig. 1 Located in the biggest estuarine systems of the Pacific coast of South America, Guayaquil's urban expansion has largely occurred on mangrove areas leading to the desiccation and disappearance of many branches of the Salado Estuary, which today is part of the National System of Protected Areas (Elaborated by: Maria Fernanda Ordóñez' elaboration based on cartography from the Geographic Military Institute, 2013 and Ministry of Environment)

2013), different versions of the Guayaquil Ecologico Project elaborated by the MAE (2010, 2015, 2016, 2018) MIDUVI $(2011,2013,2015)$ as well as literature analysis of academic sources, press releases and newspaper articles. Information from notes and transcripts was coded thematically and then analysed using thematic analysis on the level of impact, acceptance and use of the linear park in relation to the Buen Vivir objectives.

\section{Discussion and evaluation}

\section{Rhetoric and realities of Guayaquil Ecológico}

The project's political context was based on contrasts between the former right-wing Social Cristino mayor 


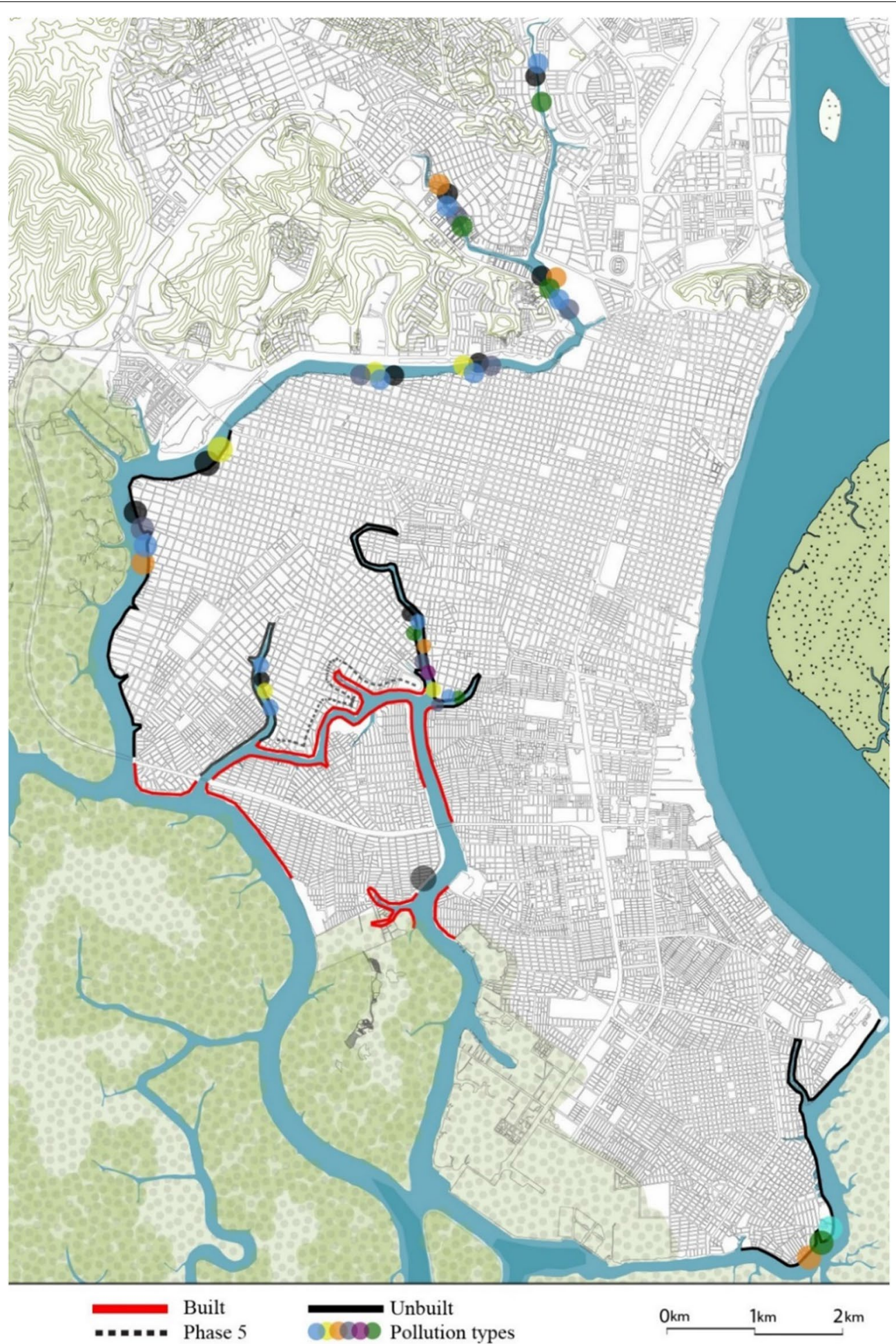

Fig. 2 The Guayaquil Ecologico linear park sought the socio-ecological regeneration of the Salado Estuary. It was implemented to prevent the expansion of self-built dwellings and to halt further pollution from direct wastewater discharge (Elaborated by María Fernanda Ordóñez based on cartography from the Geographic Military Institute, 2013 and Ministry of Environment) 
Jaime Nebot, and the progressive national government, led by former president Rafael Correa. Nebot represented the local elites envisioning a city with its own political autonomy and introducing new form of municipal administration based on public-private partnerships where private foundations-managing public fundswere stablished to oversee urban regeneration projects. Correa, openly critised this form of municipal administration challenging the hegemony of the city's elites and believing in the capacity of the State to plan and order social, territorial and economic processes, thus, in a geopolitical context, the linear park became the counterproject of Malecon 2000.

The linear park represented a political statement of a progressive national agenda that used the Buen Vivir and Rights of Nature discourse to address issues of socioecological injustice for vulnerable population along the Salado Estuary deemed as 'forgotten' by the Social Cristiano government. In February 2010, during a televised weekly report to the nation, Correa stated 'We are going to intervene in Guayaquil with the project "Guayaquil Ecológico" - a city with a strong environmental problem due to the catastrophic Social-Cristiano-political practices that allowed the estuary and hills to be invaded and destroyed-to convert it into the ecological city it always had to be, a successful model of justice and equality'(quoted in Sanchez Gallegos 2017:49). During inauguration of phase six (2017), Correa referred to Guayaquil Ecológico as an 'access-free green area' exposing the highly criticised exclusionary practices and controlled activities imposed by the local government in public spaces in certain areas of the city (Andrade 2006) Nevertheless, the following paragraphs demonstrate how in practice Phase 5 of linear park - as the outcome of a hierarchized, top-down design approach-was in contradiction with the non-hierarchical, collaborative and pluralistic vision of the Buen Vivir rhetoric which advocates for a collective, and heterogeneous construction of a new societal model and calls for a recognition of the " value of experiences, visions and ideas of those who have a long, deep and marginalized history (Acosta and Martinez Abarca 2018:134) and, paradoxically the concept was used to justify actions that perpetuated socio-environmental vulnerabilities creating new realities of abandonment and exclusion in the name of social upgrading and ecological restoration.

Exasperated vulnerabilities through evictions and relocations As means to achieve the desired ecological restoration of the estuary, and complying with constitutional articles 72' nature has the right to be restored' and objective 7 of the BVNP, 'To guarantee nature's rights and to promote a healthy and sustainable environment', the project developed several activities which included, amongst others, environmental education, wastewater discharge control, as well as relocation of homes at risk (MAE and MIDUVI 2013:11) to the social housing program Socio Vivienda I, II and III, located in the periphery of northern Guayaquil. The argument was made that, in order to push environmental restoration, self-built housing which occupied the estuary and was polluting it, needed to be removed. The project identified 32,700 people living in precarious conditions along the estuary, with overcrowding and highly polluted water resulting from direct domestic or industrial discharge. By 2014, a total of 15,068 people had been relocated (MIDUVI 2015:10) and another 9,608 inhabitants were planned to be relocated in situ by the end of the project (2017).

However, the so-called ecological restoration of the area-a process of assisting the recovery of an ecosystem that has been degraded or destroyed-was not properly addressed from the beginning. Studies have shown extreme pollution of the estuary in both informal and formal areas (i.e., URDESA) which has been systematically acknowledged by the Guayaquil Ecologico project. 'Studies carried out since 2010, describe that the situation of the Salado Estuary in the interior sections known as A (URDESA-Kennedy) and B, (URDESA-Miraflores) are affected by the discharge of industrial and domestic waters with high biochemical oxygen demand (...) and low oxygen concentrations, reaching anoxic conditions mainly at low tide. The sludge present in these sections also show high concentrations of sulfides, high biochemical oxygen demand and high concentrations of mercury and lead.' (MAE 2010, 2015, 2018). However, major actions leading to the ecological upgrading of the Salado Estuary did not involve the northern branches (A and $B)$, but rather focused on removing the self-constructed units along the estuary. The aforementioned ministerial documents continue to describe 'Another factor that produces a negative visual effect and affects the quality of the water is the solid waste in the interior branches of the Suburbio'. Although wastewater discharge was identified as a key issue to be addressed, this was not as high a priority as the relocation of low-income settlements. This is evident from the project's budget allocation for 2010-2017 where a total of $\$ 2,900,000$ was allocated for wastewater identification and monitoring versus $\$ 64$ million for housing relocation (MAE and MIDUVI 2013:72). It wasn't until 2015 that 'Correa recognised that it was not possible to restore the stuary without first providing sanitary infrastructure to the families living on its borders (...) finally the national government facilitated the granting of a loan from the World Bank and the European Central Bank for $\$ 102,5$ million for the sanitary infrastructure' (Portaluppi 2019:38). 
In this sense, the Guayaquil Ecologico linear park implied a form of greenwashing whereby beautification conveniently operated as means to halt self-building. In line with constitutional article 73,'The State shall apply preventive and restrictive measures on activities that might lead to the extinction of species, the destruction of ecosystems and the permanent alteration of natural cycles' the national government's desire for socio-spatial upgrading and ecological restoration of the Salado Estuary was (conveniently) met with a zero-tolerance policy towards informal settlements. ${ }^{3}$ Lopes de Souza (2016), writes, 'urban eco-geopolitics is above all related to strategies of socio-spatial control apparently designed to prevent people from 'degrading the environment', though in fact they have several social and spatial implications.' (Lopes de Souza 2016:1). This research revealed that the Rights of Nature rhetoric was conveniently used to legitimise the eviction processes in the name of Suburbio's nature along the estuary. At the same time, the housing program Socio Vivienda I was built in the Security Reserve Area for the Santa Elena Aqueduct Hydraulic Plan (MIDUVI 2013:1) which is considered an ecologically sensitive area next to the ESPOL University protected forest (MIDUVI 2011:19).Therefore, Socio Vivienda's implementation paradoxically neglected every notion of nature conservation or integration within planning proposals and rather followed an 'industrial planning philosophy: build as many units as possible, as cheaply and efficiently as possible. (Salingaros et al. 2019).

The social disruption caused by the evictions would render a new socio-spatial reality for both those staying and those leaving. The forced relocation meant the rupture of a long-forged social fabric and mingling of previously unknown groups that-according to local news reports-turned Socio Vivienda into 'one of the most violent areas of Guayaquil' (Letamendi 2020) where five police interventions have taken place to stop criminal activities, the last one needing 500 police members (Universo 2020). Inhabitants were not only forced to dispense of their assets such as location, land, social capital and voice (Anguelovski et al. 2018:135), but also of their social control. The interviews revealed a general acknowledgement by all the stakeholders about the unforeseen social consequences of the evictions that particularly affect the relocated population, 'they don't want those houses, because of their small size, and because of the deep social problem which is always on the news' ( $\mathrm{r} 1)$, 'there are thieves in Socio Vivienda' (r7). The local expert refers to this area as Ghetto Vivienda denouncing the critical social circumstances resulting from ruptured community ties that exerted control measures over the "bad boys". Former project officials added 'some people take their bad habits with them where they go. If any irregularity is detected, the house can be taken away' (d). In addition, interviews further confirmed the socio-economic connections identified in previous studies (Bayón et al. 2020; Peek et al. 2018) where an undetermined number of people maintain socio-economic linkages to the Suburbio as some of them have chosen to return to live near the estuary, while others still maintain their daily work activities in the area despite its distance. 'They distribute their fruit here, but they live in Socio Vivienda an hour and a half away. They take two buses' ( $\mathrm{r} 1$ ), another resident adds 'They work in VISOLIT ${ }^{4}$ but they come from Socio Vivienda, the guard lets them in past entrance time, he knows they live far' (r7). In this manner, despite the large population that has been claimed as direct beneficiaries of this project (786,332 people) its implementation has had quite a large (negative) socio-spatial impact far beyond their immediate surroundings, including Socio Vivienda where the Buen Vivir principles are virtually non-existent. Its peripheral location, lack of legal ownership of the houses, insufficient infrastructure, minimal space and overcrowding, lack of green areas and unsafe environment, render this population highly vulnerable and, therefore, the state-led approach by the progressive government 'continue, rather than rupture with previous neoliberal territorial models'(Durán et al. 2020:36).

Despite having its genesis in a biocentric constitution, the Guayaquil Ecológico project has in fact, very little to do with ecology and was rather based on aesthetics and quantitative indicators for green space allocation. The project's main goal suffices as evidence and exposes the conflict that surfaces when trying to reconcile the right to nature and the right to housing on the territory. While objective seven from the BVNP states a claim 'to guarantee nature's rights and to promote a healthy and sustainable environment,' the ministry-led mega-project claims its priority 'to provide the population of Guayaquil with sufficient green areas for recreation, contact with nature and to promote the permanent creation of environmental services for the city' (MIDUVI 2015:7) Another document adds: 'with the aim of structuring decent cities for their inhabitants and that they achieve a harmony between the natural environment and the built space that allows them to achieve Buen Vivir' (MAE 2015:14).The project's initiation came with a series of quantitative indicators, including one of green space allocation, wherein Guayaquil registered a deficit, with $1.12 \mathrm{~m}^{2} /$ inhabitant versus the $9 \mathrm{~m}^{2} /$ inhabitant suggested by the World Health 


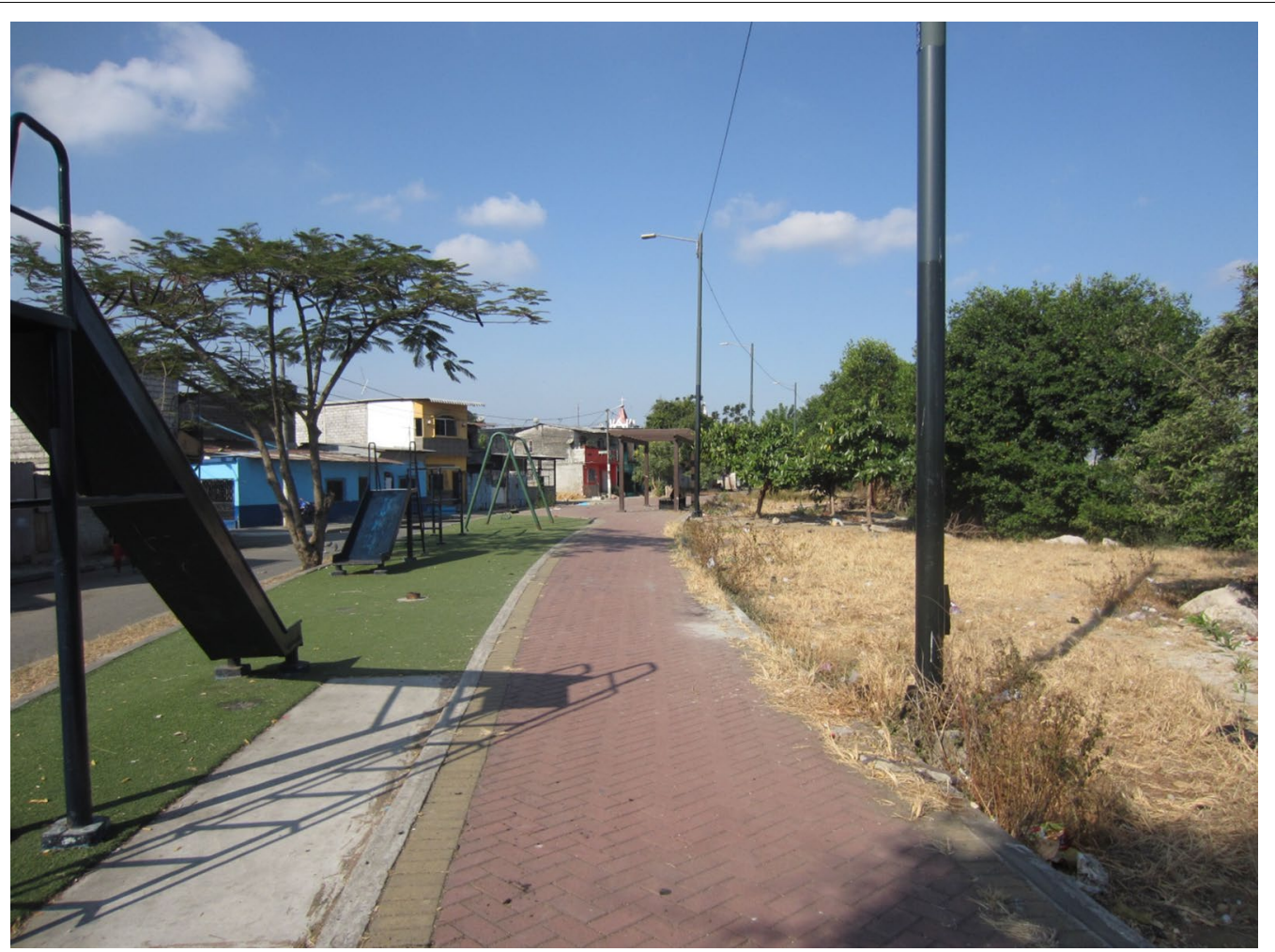

Fig. 3 Play equipment, artificial grass, hard paving and re-naturalised waterfront banks in El Cisne II neighbourhood in Phase 5 (source: María Fernanda Ordóñez 2019)

Organisation. Consequently, from its inception, the project was essentially human-focused. In fact, without the purpose to serve human interests, Guayaquil Ecológico may have never come to exist.

The intervention of the linear park component along the Salado Estuary was a missed opportunity to address nature's rights through meaningful ecological restoration. Given that the constitution does not hierarchise one set of rights over the other-nature over human or vice versa-the spatial implementation of the rights of nature are subordinated to those of humans. In this sense, aligned with waterfront redevelopment strategies previously executed in the city, the linear park removed 3,478 families (MIDUVI 2015:10) to create a $2.40 \mathrm{~m}$ wide and $15.8 \mathrm{~km}$-long colourful cemented pathway with carefully delineated green areas (including artificial grass), shrubs, and scarce trees. Scattered throughout the new 'natural' landscape are various public amenities, including fitness equipment, playgrounds, benches and sport courts, contemplation zones and small harbours. Green space implementation included reforestation activities where possible, but all limited due to extreme water and soil contamination. Mangrove reforestation activities took place between 2012 and 2013 in Estero del Muerto, Estero Mogollon and Estero Cobina. However, the outcome was a far cry from the once-thick native mangrove forests that once hosted great biodiversity. As indicated by a biologist working on the project 'due to the level of pollution, mangroves in those areas only reached $1 \mathrm{~m}$ height, whereas healthy mangroves can reach up to $15 \mathrm{~m}$ height'(b). Additionally, in Phase five, environmental restoration included the implementation of forty 'floating islands' in the Estero Palanqueado that were designed to decontaminate natural water bodies through bacteria growing on native vegetation planted on them. Overall, the sum of these activities in the Suburbio, contributed to a partial cleansing of the estuary's waters and to the general improvement in the landscape scenery, at least in the beginning which leads to the following discussion (Figs. 3, 4).

\section{Neglect, abandonment, and exclusion}

Based on the assumption of positive impacts derived from green infrastructure implementation, (Benedict and McMahon 2000; Vásquez, et al. 2019) the project claims to provide a common space that promotes social cohesion, territorial integration and upgrade the quality of life of the population (objectives 2,3,4). For this reason, it is considered to be 'not only an urban project, but a social project' (d). Based on interviews with residents, although 


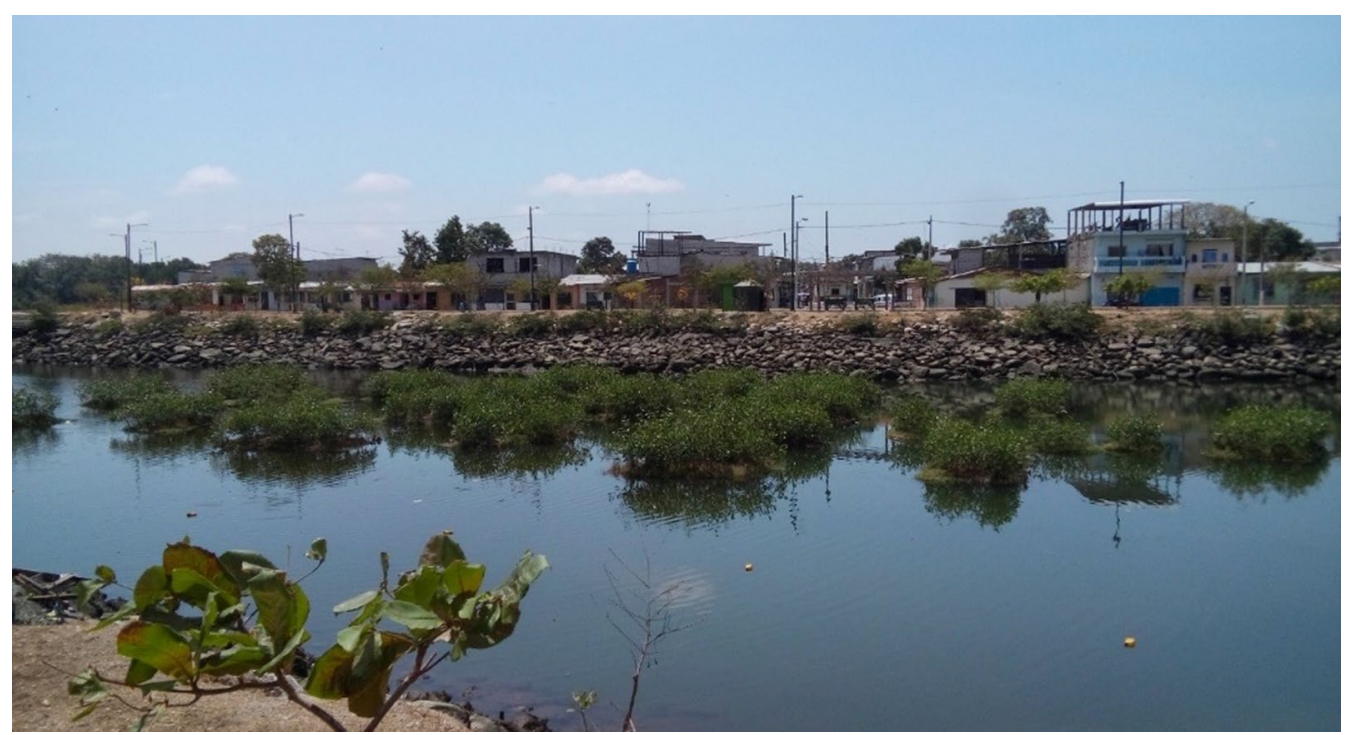

Fig. 4 Artificial islands to decontaminate the water in the Estero Palanqueado in Phase 5 (source: María Fernanda Ordóñez 2018)

the beautification and restoration efforts were appreciated and positively accepted, they all agreed on the ephemerality of this condition, 'this was beautiful, look at it now'(r7). Some residents even differentiated the political actors behind the maintenance of particular projects in Phase 5 where, an urban regeneration project executed by the municipality meets the linear park executed by the national government. 'They take care of this park, Nebot's park. Here they come to pick up the garbage. It doesn't happen in Correa's park' (r11). Another resident adds 'they used to water the plants every three days, then Correa left, and they stopped. The plants haven't been watered once this summer' (r1). Similarly, officials from the Guayaquil Ecologico project repeatedly stated that with the end of the Correa era (2007-2017), the project was not a national priority anymore. The budget cuts implied the reduction of personnel, going from $28 \mathrm{mem}$ bers between social, technical and administrative staff to only four members, according to the former director of the project: 'two technicians, a secretary and myself'. The disappearance of the entire social team, who worked in-situ, was partially the cause of the park's current state of neglect as their job consisted not only in working with the community to generate a sense of appropriation of the park, but also reporting on any case of vandalism leading to the replacement of stolen items. This is supported by the words of another inhabitant: 'they stole the electric cables, but they were replaced twice' (r1). However, not all accounts agree on this timing, many of the locals point out the rapid decline of the project only a few months after its implementation 'in a matter of two months, this was a disaster' (r4).
The initial enthusiasm of the community adjacent to the park has decreased as the clearance of space through evictions led to a new form of occupation far from the 'landscapes of pleasure and privilege' (Anguelovski et al. 2018:134) but rather dominated by substance-dependent groups-locally known as 'hacheros." Their constant presence renders the park as unpleasant and unsafe, particularly for external visitors, the park is therefore consciously avoided and underused. 'They (the hacheros) live there now. They carry blankets and lay on the kid's playing equipment, so people are somewhat afraid to go there' (r1). Moreover, they take advantage of the existing vegetation, particularly mangroves, to hide/live in makeshift dens, thus in Phase 5, inhabitants destroyed clusters of mangroves since they are perceived as dangerous hiding spots. An inhabitant claimed that 'residents themselves cut them down, it is dangerous' ( $r 4$ ), they prefer to have open views in order to be more aware of their surroundings. The sense of unease in the park is acknowledged by all actors. The local expert adds: 'the park is a marginal site. It is a park that is designed to stop occupations, to stop invasions and although it is true that there are walking areas, gardens and playing equipment, it is now being used much more by subaltern groups, by mafias and drug users than by inhabitants' (le). Project officials stated: 'not everything is nice and easy in the linear park. There is drug trafficking taking place. People vandalise the area and steal security cameras because they don't want to be monitored' (a). Currently, the park is in an alarming

\footnotetext{
${ }^{5}$ People that use a mixture of heroin and cocaine base known as ${ }^{\mathrm{H}} \mathrm{H}$
} 


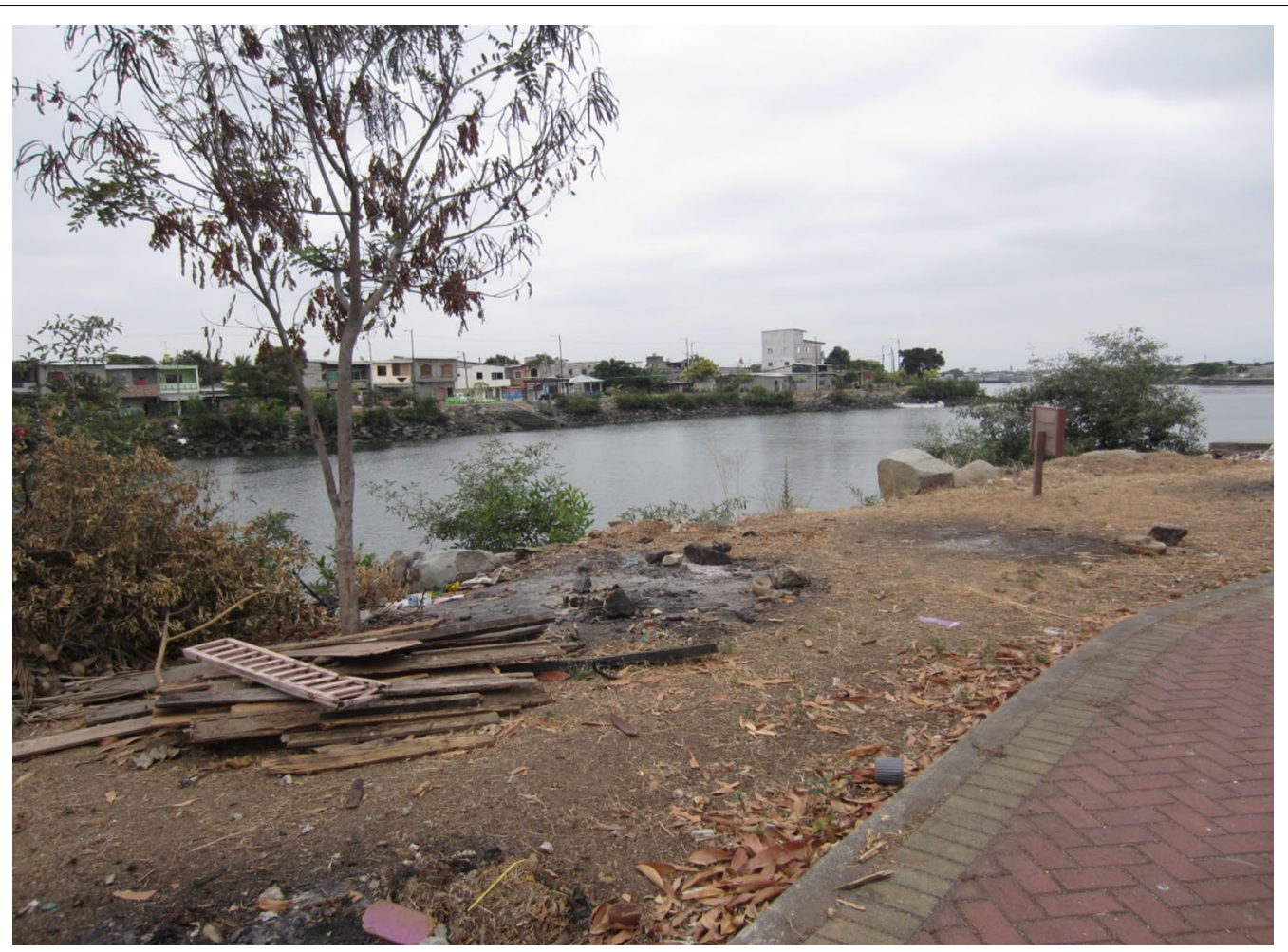

Fig. 5 Area where vegetation was cut down (source: María Fernanda Ordóñez 2019)

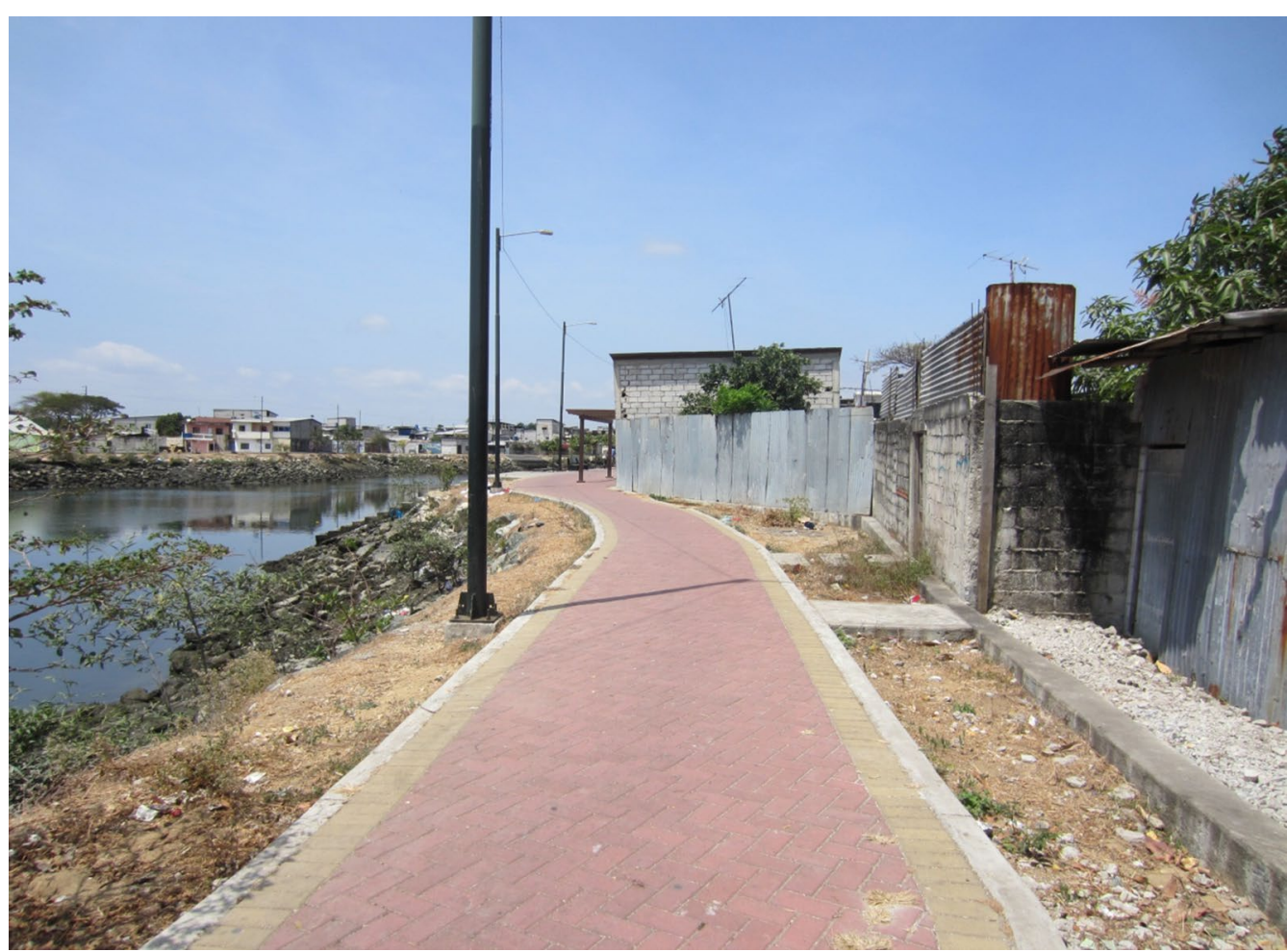

Fig. 6 Neglected spaces of the park and dried grass (source: María Fernanda Ordóñez 2019) 


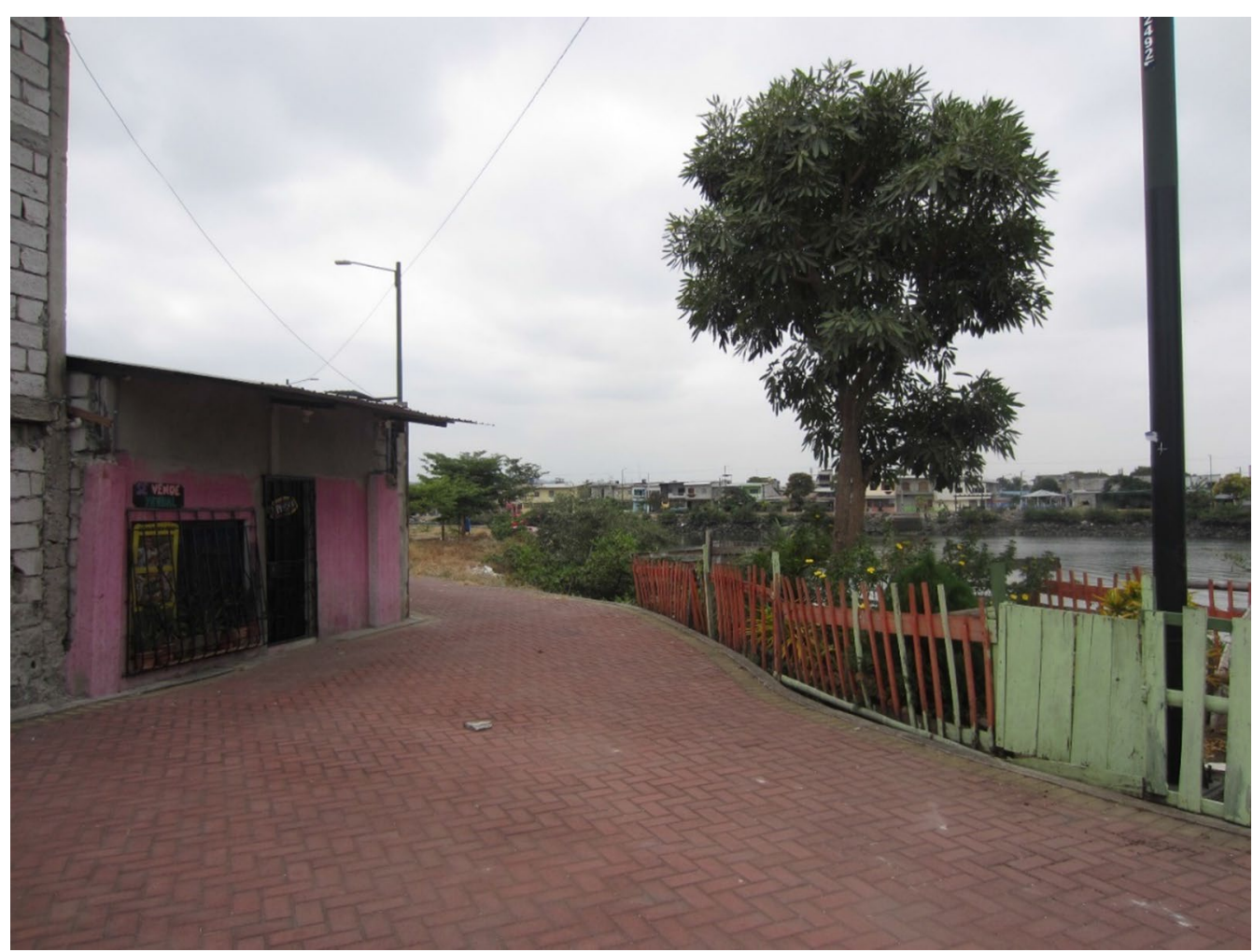

Fig. 7 Small private orchard as an appropriated space. (source: Maria Fernanda Ordóñez 2019)

state of neglect. Fitness equipment and playgrounds are vandalised, and patches of artificial grass have been stolen. The network of underground electricity cables has been taken, which necessitated the fallback to an openair network of high poles. In addition to the critical comments already mentioned, a number of inhabitants point to unruly community members who don't comply with garbage collection schedules causing the hacheros to rip open the garbage bags and spreading the contents along the shore as they look for items to sell (Figs. 5, 6).

In this context, the research has found that although the park is seen as a positive intervention that improved the urban landscape and offered a new public space, at the same time there is an explicit acknowledgement by all parts regarding the constant presence of non-welcoming groups which create a sense of unease especially for visitors who are considered 'strangers' in the area, therefore susceptible to harm. During the interviews, all of respondents emphasized the lack of maintenance, which includes watering plants and garbage collection, as well as security measures. All agreed on the need of guards and of police presence claiming that if there were guards, it will be safer for kids' ( $\mathrm{r} 5$ ) or that their presence is needed 'to control some people' (r8). Others added 'this was a touristic area because guards and police were here' ( $\mathrm{r} 4)$. In some areas, inhabitants have acted as custodians of their own 'parcel' of the park and sporadic signs of appropriation can be found in certain spots, usually as extension of their private property in the form of small orchards where inhabitants have planted their own fruit trees and have fixed benches. In other occasions, the appropriation occurs to keep the hacheros away by pouring hot oil or broken glass in specific places of the linear park. In sum, based on the interviews and direct on-site observation, the park is somewhat used by inhabitants with different levels of intensity depending on the time of day and familiarity to the area but is highly avoided by outsiders since it is perceived as dangerous. A project that promoted social integration and territorial cohesion has not come to fruition since the park remains a marginal place within an area that is already socially and spatially excluded from the city (Figs. 7, 8 and 9).

\section{Conclusion}

Although Ecuador's legal framework of the "Rights of Nature" and the Buen Vivir vision is bold and stated with admirable rhetoric its practical implementation remains a challenge to overcome without recognizing and integrating a diversity of knowledges, experiences and the complex socio-economic realities resulting from years of 


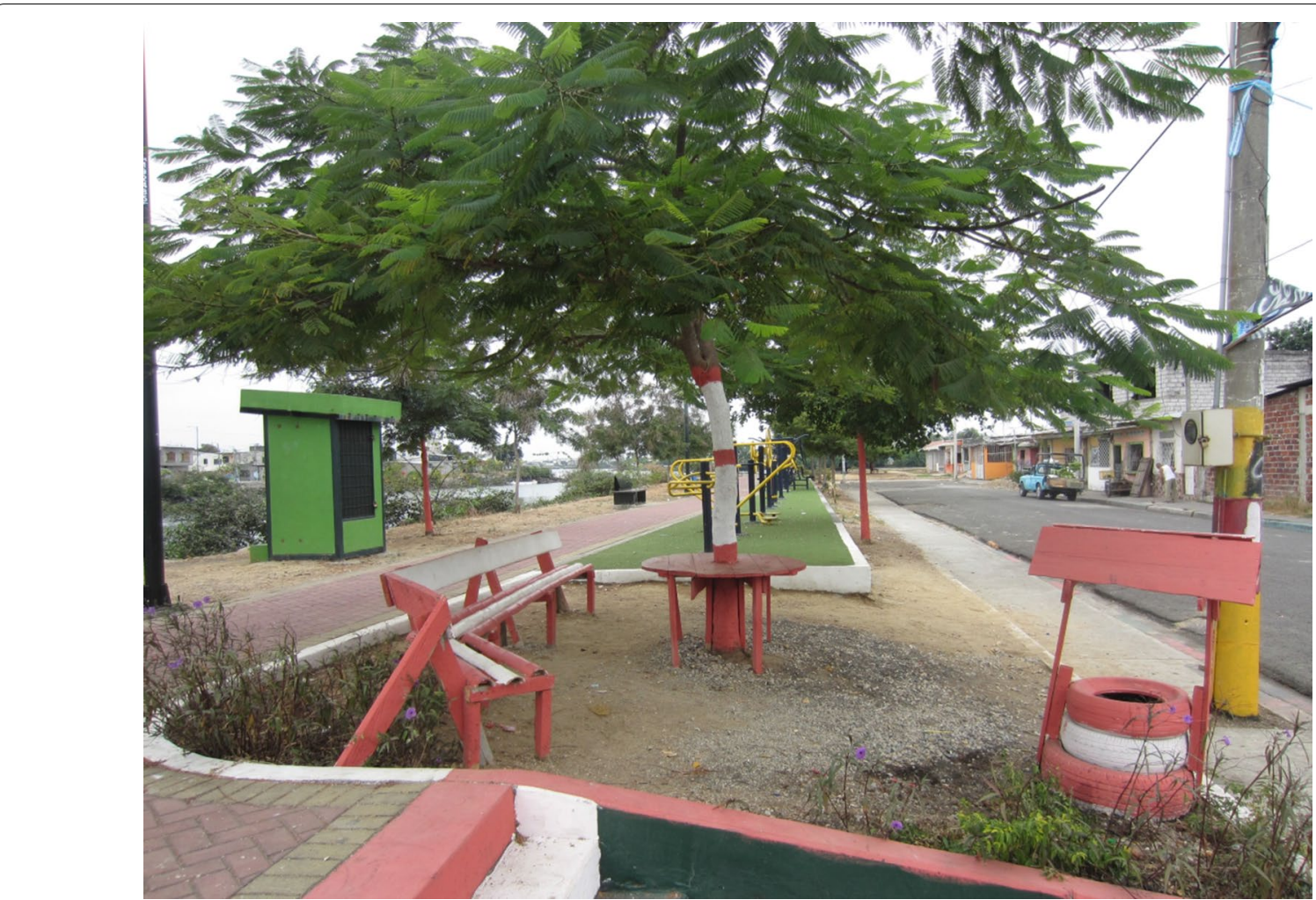

Fig. 8 Spaces appropriated by the neighbours for communal use. (source: María Fernanda Ordóñez 2019)

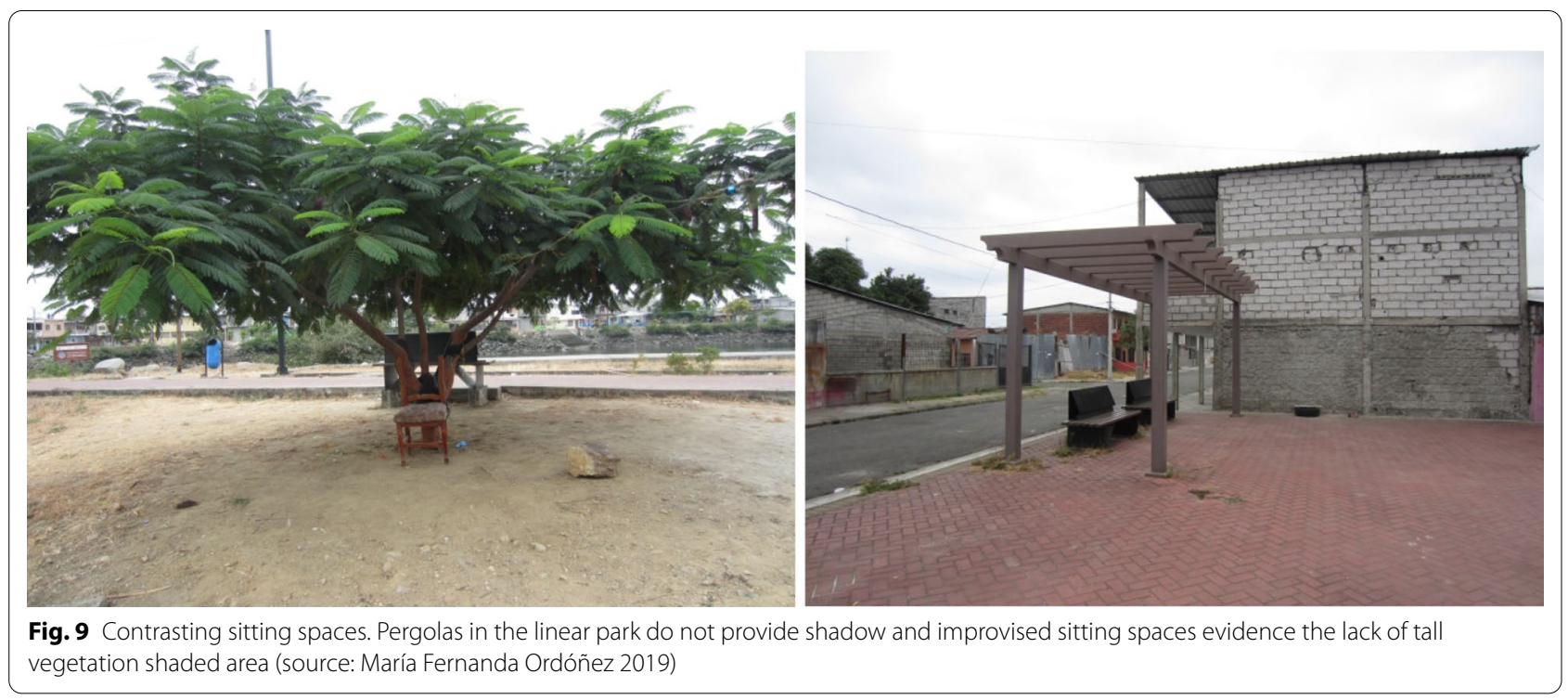

structural injustice evidenced across a range of scales and dimensions. This research has found that although Phase 5 of the linear park was initially received with enthusiasm by non-relocated residents, it soon fell into a state of abandonment and neglect and further exasperated conditions of vulnerability for its relocated population. Its implementation did neither successfully achieve the social, nor the ecological objectives it establisheddespite claiming to do so. It became more a pacification project, a gesture to upgrade people's lives and whose 
fortune appears to have been dependent on a particular political figure and momentum.

Often, urban regeneration projects and green infrastructure implementation come as 'fixers' that upgrade former industrial sites, channelized river edges, and over-exploited land, etc. that are the outcome of a global culture of capitalism. Phase 5 of the linear park serves as testimony for unfulfilled promises resulting from a dislocation between a biocentric constitution and an anthropocentric design born from a hierarchical, topdown approach to urban and socio-ecological regeneration where an unilateral vision and ideal of public green space was imposed on a place with its own dynamics and logics. Local knowledge, needs and socio-economic dynamics were mostly excluded resulting in socio-spatial strategies that further continued -and relocated- socioenvironmental vulnerabilities. In this regard, efforts have been made to address this disarticulation including the international summer school workshop Designing Inclusion between KU Leuven and Universidad of Guayaquil in 2015 aimed to develop a 'participatory urban design to solve the conflict between the megaproject and affordable housing for the vulnerable population' (d'Auria et al. 2015) for some of the unbuilt phases.

The Buen Vivir philosophy -as a decolonial stance that challenges western notions of development-can offer a fundamental base to question current modes of territorial occupation based on extractivist planning and design strategies. It holds significant potential to serve as base to re-think the relationship between forms of settlement, natural dynamics and worldviews. Referring back to Gudynas 'the recognition of the rights of nature imposes severe conditions over the acceptable ways in which to interact with nature' (Gudynas 2011b:88) and this evidently includes urbanism. In planning and urbanism, the demarcation of conservation areas is the materialization of the Rights of Nature par excellence, however, it does not guarantee their integrity. In Latin America, - particularly in the last decade in Ecuador and Bolivia, with strong socialist governments who recognized the Rights of Naure - the attempts to build a more just society implied the creation and strengthening of ambitious social programs financed by large scale mining and oil exploitation that continue to commodify nature contradicting the essence of the Buen Vivir. In this sense, Escobar (2010) writes 'there is an asymmetry in the Plan (the BVNP), between those elements that contribute to economic growth, and those which could make viable social and environmental strategies for the Buen Vivir' (Escobar 2010:22). So far, scholars writing about Buen Vivir have strongly questioned an economic model based on extractivism, but haven't questioned other forms of 'extraction' including urbanisation as the outcome of current planning orthodoxy where 'local space is not identified as a resource in itself, except in its most basic form: available land' (Loeckx and Shannon 2004:158). Therefore, The Buen Vivir as a different philosophy of life which 'enables the subordination of economic objectives to the criteria of ecology, human dignity and social justice'(Escobar 2016:26) holds the unique promise to support, justify, and even promote design explorations that constructively address the perpetual tensions between human settlements and ecosystems. The Buen Vivir 'cannot be improvised -it must be planned. Buen Vivir is the style of life that enables happiness and the permanency of cultural and environmental diversity; it is harmony, equality and solidarity. It is not the quest for opulence or infinite economic growth' (SENPLADES 2013:14) to do so, however, designers and planners must invert stablished and conventional approaches to design that rupture with dualistic discourses and positions of formal-informal, city-nature, urban-rural, humans and non-humans, etc. and 'open space to other imaginations and forms of habitat and living, different from the modernist city' (Escobar 2017:108) in this sense, "urbanism is uniquely able to synthesize ecological systems, scientific data, engineering methods, social practices and cultural values integrating them into the design of the built environment' (Shannon 2020:20) The challenge ahead, for cities of the twenty-first century already facing the consequences of multidimensional crises (sanitary, environmental, socioeconomic) to only be worsened by a warming planet is to radically re-think our relationship with nature and, urbanism - through design and its creative capacity can help influence policy and mobilise structural change by successfully embracing multitude of realities, visions, actors that aim for an urban development and progress that are both socially and ecologically just territories.

\section{Acknowledgements}

Not applicable.

\section{Authors' contributions}

Aside from fieldwork and translation from Spanish texts and interviews executed by first author, this article has been jointly written by all authors in all parts. All authors read and approved the final manuscript.

\section{Funding}

This article is part of a Ph.D. research study program funded by the Ecuadorian National Secretary of Higher Education Science and Technology and Innovation (SENESCYT).

\section{Availability of data and materials}

Data supporting the conclusion is included within the article.

\section{Competing interests}

We declare that we have no competing interests.

Received: 5 November 2020 Accepted: 30 December 2021 Published online: 11 January 2022 


\section{References}

Acosta A (2008) La Naturaleza como Sujeta de derechos. Retrieved August 3 , 2020, from Red de Ecologia Social website: http://ecologiasocial.com/ 2008/03/la-naturaleza-como-sujeta-de-derechos/

Acosta A (2009) La Maldición de la Abundancia (1st ed.). https://www.rebelion. org/docs/122604.pdf

Acosta A (2015) El Buen Vivir como alternativa al desarrollo Algunas reflexiones económicas y no tan económicas. Politica y Sociedad 52(2):299-330. https://doi.org/10.5209/rev-POSO.2015.v52.n2.45203

Allan Alegria HP (2010) Regeneracion Urbana y Exclusion Social en la Ciudad de Guayaquil. FLACSO

Acosta A, Martinez Abarca M (2018) Buen Vivir: An alternative perspective from the peoples of the Global South to the crisis of capitalist modernity. In: Satgar V (ed) The Climate Crisis: South African and Global Democratic Eco-Socialist Alternatives. Wit University Press, Johannesburg, pp 131-147

Andrade X (2006) Mas ciudad, menos ciudadania. In: Rivera F (ed) Ecuador Debate, 68th edn. Quito, CAAP, pp 161-198

Anguelovski I, Shi L, Chu E, Gallagher D, Goh K, Lamb Z, Teicher H (2016) Equity impacts of urban land use planning for climate adaptation: critical perspectives from the global north and south. J Plan Educ Res 36(3):333-348. https://doi.org/10.1177/0739456X16645166

Anguelovski I, Irazábal-Zurita C, Connolly JJT (2018) Grabbed Urban Landscapes: Socio-spatial Tensions in Green Infrastructure Planning in Medellín. Int J Urban Reg Res 43(1):133-156. https://doi.org/10.1111/ 1468-2427.12725

Bayón M, Durán G, Bonilla Alejandra Hernández F, Araujo M, Andrade S, Santelices C, Villavicencio J (2020) II. Guayaquil: Renovación ecológica y vivienda social en las periferias. In: Duran G, ed. Contested Cities Ecuador: Territorios en disputa y autoproducción de hábitat popular en el marco de la nueva agenda urbana global (pp. 2-37). Quito: FLACSO Ecuador

Benedict MA, McMahon ET (2000) Green Infrastructure. Recreation 37:4-7. https://doi.org/10.4135/9781412973816.n70

Calisto Friant M, Langmore J (2015) The buen vivir: a policy to survive the Anthropocene? Global Pol 6(1):64-71. https://doi.org/10.1111/1758-5899. 12187

Childers DL, Cadenasso ML, Morgan Grove J, Marshall V, McGrath B, Pickett STA (2015) An ecology for cities: a transformational nexus of design and ecology to advance climate change resilience and urban sustainability. Sustainability (switzerland) 7(4):3774-3791. https://doi.org/10.3390/ su7043774

Crutzen PJ, Stoermer EF (1999) The" Anthropocene "Contribution to the regional data bundle concept : the IGBP-DIS-MEDIAS-France partnership. Global Warming Reader 4(7):17-18

d'Auria V, Carolifis N, Peek O, Scheers J, Sanchez Gallegos P, Rivera M (2015) Designing Inclusion.Coproducing ecological urbanism for inclusive housing transfor- mation. [VLIR-UOS. https://designinginclusion.wordp ress.com/

Durán G, Bayón M, Mena AB, Janoschka M (2020) Social housing in ecuador: territorial violence, contestations, and peripheral urban space production. Revista INVI 35(99):34-56. https://doi.org/10.4067/S0718-8358202000 0200034

Escobar A (2010) Latin America at a crossroads: Alternative modernizations, post-liberalism, or post-development? Cult Stud 24(1):1-65. https://doi. org/10.1080/09502380903424208

Escobar A (2016) Thinking-feeling with the earth: Territorial struggles and the ontological dimension of the epistemologies of the south. AlBR Revista de Antropologia Iberoamericana 11(1):11-32. https://doi.org/10.11156/ aibr.110102e

Escobar A (2017) Autonomia y Diseño la Realizacion de lo Comunal, 1 ra edn. Tinta Limón, Buenos Aires

FAO (2021a) Banana market review. Preliminary results 2020. http://www.fao. org/3/cb5150en/cb5150en.pdf

FAO (2021b) Information and Analysis on World fish trade. http://www.fao.org/ in-action/globefish/market-reports/resource-detail/en/c/1416629/

Gaber J (2020) Qualitative Analysis for Planning and Policy: beyond the numbers, 2nd edn. Taylor \& Francis, New York

Gandy M (2018) Cities in deep time: bio-diversity, metabolic rift, and the urban question. City 22(1):96-105. https://doi.org/10.1080/13604813.2018. 1434289
Garcia Alvarez S (2015) Environmental policies and Pachamama in Ecuador. Theory and practice in Rafael Correa 's Government. Environ Policy Decis Making 1(3):227-239

Gudynas E (2011a) Buen Vivir : Today 's tomorrow. Development 54(4):441447. https://doi.org/10.1057/dev.2011.86

Gudynas E (2011b) Desarrollo, Derechos de la Naturaleza y Buen Vivir después de Montecristi. In G. Weber (Ed.), Debates on cooperation and models of development. Perspectives from the civil society en Ecuador. (pp. 83-102). Quito: Centro de Investigaciones CIUDAD y Observatorio de la Cooperacion de I

Gudynas E (2011c) Tensiones, contradicciones y oportunidades de la dimension ambiental del Buen Vivir. In I. Farha \& L. Vasapollo (Eds.), Vivir bien: Paradigma no capitalista? (first, pp. 231-246). La Paz: CIDES-UMSA

Hidalgo-Capitán AL, Cubillo-guevara AP, Medina-carranco N, Hidalgo-capitán AL, Cubillo-guevara AP, Medina-carranco N (2019) Los Objetivos del Buen Vivir Una propuesta alternativa a los Objetivos de Desarrollo Sostenible. Good Living Goals An alternative proposal to the Sustainable Development Goals. Ibe-Roamerican Journal of Development Studies, 8(1), 6-57. https://scihubtw.tw/https://dialnet.unirioja.es/servlet/articulo?codigo= 6933773

IPCC (2021) Climate Change 2021: The Physical Science Basis. Contribution of Working Group I to the Sixth Assessment Report of the Intergovernmental Panel on Climate Change. (V. Masson-Delmotte, P. Zhai, A. Pirani, S. . Connors, C. Pean, S. Berger, B. Zhou, Eds.). Cambridge University Press

KauffmanMartin MLP (2018) Construting rights of nature norms in the US, Ecuador, and New Zeland. Global Environ Politics 18(4):43-62. https://doi. org/10.1162/GLEP

Klein N (2014) This changes everything. Capitalism vs the climate. Alfred A. Knopf Canada, Toronto

Kolbert E (2014) The sixth extinction: an unnatural history. Bloomsbury Publishing PLC, London

Kotzé LJ, Villavicencio Calzadilla P (2017) Somewhere between rhetoric and reality: environmental constitutionalism and the rights of nature in Ecuador. Transnational Environ Law 6(3):401-433. https://doi.org/10.1017/ s2047102517000061

Lalander R (2014) Rights of nature and the indigenous Peoples in bolivia and Ecuador : a Straitjacket for Progressive development Politics? derechos de la naturaleza y los pueblos indígenas en bolivia y Ecuador : ¿ Una camisa de fuerza para las políticas progresistas de d. Iberoamerican J Devel Stud 3(2):148-173

Leff E (2012) Latin American environmental thinking: a heritage of Knowledge for Sustainability. Environ Ethics 34(4):431-450. https://doi.org/10.5840/ enviroethics201234442

Letamendi X (2020) Socio Vivienda el plan habitacional que se convirtio en el barrio mas violento de Guayaquil. PRIMICIAS. https://www.primicias.ec/ noticias/sociedad/socio-vivienda-plan-habitacional-barrio-peligrosoguayaquil/

Loeckx A, Shannon K (2004) Qualifying Urban Space. In: Loeckx A, Shannon K, Tuts R, Verschure H, eds. Urban Trialogues: Visions, projects, co-productions, Localising Agenda 21 (pp. 157-168). Nairobi: UN-HABITAT

Lopes de Souza M (2016) Urban eco-geopolitics: Rio de Janeiro's paradigmatic case and its global context. City 20(6):779-799. https://doi.org/10.1080/ 13604813.2016 .1239443

MAE M of E (2010) Generacion y Restauracion de areas verdes de la ciudad de Guayaquil. Guayaquil Ecologico (p. 49). p. 49. Guayaquil

MAE M. of E (2015) Proyecto de recuperacion de las areas protegidas de la ciudad de Guayaquil. Estero Salado e Isla Santay (p. 68). p. 68. Guayaquil

MAE M of E (2016) Ecuador Protected Areas

MAE M. of E (2018) Proyecto de recuperación de las áreas protegidas de la ciudad de Guayaquil: Estero Salado e Isla Santay. (p. 122). p. 122. https://www. ambiente.gob.ec/wp-content/uploads/downloads/2015/07/ESTEROSALADO.pdf

MAE, M. of E.and MIDUVI, M. of H (2013) Gereracion y restauracion de Areas verdes para la ciudad de Guayaquil. Guayaquil Ecologico (p. 94). p. 94. Guayaquil

Meyer CB (2001) A Case in Case Study Methodology. Field Methods 13(4):329_ 352. https://doi.org/10.1177/1525822X0101300402

MIDUVI, M. of H. and U. D (2011). Proyecto Nacional de Desarrollo Urbano (p. 62). p. 62. Guayaquil

MIDUVI, M. of H. and U. D. (2013). Proyecto Nacional de Desarrollo Urbano (p. 52). p. 52. Guayaquil 
MIDUVI, M. of H. and U. D. (2015). Generación De Áreas Verdes Y Espacios Recreativos Públicos Para La Provincia Del Guayas_Guayas Ecológico (p. 71). p. 71. Guayaquil

Miller SW (2007) Environmental History of Latin America. Choice Reviews Online. https://doi.org/10.5860/choice.37-3681

Montaño Armijos M, Sanfeliu Montolio T (2008) Ecosistema Guayas (Ecuador), Medio ambiente y Sostenibilidad. Revista Tecnológica ESPOL 21(1):1-6

OECD (2018) Biodiversity Conservation and Sustainable Use in Latin America. Evidence from environmental performance reviews. In OECD Environmental Performance Reviews. https://search.proquest.com/docview/21888 47780?accountid=14723\%0Ahttps://resolver.library.uq.edu.au/?\&genre= article\&sid=ProQ:\&atitle $=$ Biodiversity + Conservation+and+Susta inable+Use+in+Latin+America\%3A+EVIDENCE+FROM+ENVIRONMEN TAL+PERFORMANCE+REVIEWS\&title $=\mathrm{OE}$

OXFAM International (2015) Privileges that deny rights/ Extremey Inequality and the High Jacking of Democracy in Latin America and the Caribbean. Oxford

Parker J, de Baro MEZ (2019) Green infrastructure in the urban environment: a systematic quantitative review. Sustainability (Switzerland) 11:11. https:// doi.org/10.3390/su11113182

Parsons JJ (1957) Bananas in Ecuador : a new chapter in the history of tropoical agriculture. Econ Geogr 33(3):201-216

Pauleit S, Vásquez A, Maruthaveeran S, Liu L, Cilliers S (2021) Urban Green Infrastructure in the Global South. In: Shackleton CM, Davoren E, Cilliers S, du Toit M, eds. Urban Ecology in the Global South (pp. 107-143). https:// link.springer.com/https://doi.org/10.1007/978-3-030-67650-6

Peek O, Hordijk M, D'Auria V (2018) User-based design for inclusive urban transformation: learning from 'informal' and 'formal' dwelling practices in Guayaquil. Ecuador Int J Housing Policy 18(2):204-232. https://doi.org/10. 1080/19491247.2016.1265268

Pengue W (2017) Hacia el pensamiento ambiental del Sur. Recursos naturales, desarrollo y reflexiones sobre una region estrategica. In W. A. Penge (Ed.), Pensamiento ambiental del Sur (pp. 11-63). Buenos Aires: Universidad Nacional General Sarmiento

Peters K, Elands B, Buijs A (2010) Social interactions in urban parks: Stimulating social cohesion? Urban Forestry and Urban Greening 9(2):93-100. https:// doi.org/10.1016/j.ufug.2009.11.003

Pettigrew AM (1990) Longitudinal field research on change: theory and practice. Organ Sci 1(3):267-292

Portaluppi C (2019) Nuevos derechos sin nuevas políticas urbanas Estudio de caso del componente restauración ecológica del Estero Salado del proyecto Guayaquil Ecológico. FLACSO Argentina

Pope Francis (2015) ENCYCLICAL LETTER LAUDATO SI'The Holy Father Francis On Care For Our Common Home. Vatican Press. Vatican: Vatican Press

Purdy J (2015) After nature. a politics for the antrhopocene. Harvard University Press, London

Rojas Mosquera M (2020) El proceso urbano de Guayaquil: Del espacio portuario a la metrópoli

Salingaros N, Brain D, Duani AM, Mehaffy M, Philiber-Petit E (2019) Antipatterns of social housing in latin america. Retrieved June 14, 2021, from Archdaily.com website: https://www.archdaily.com/914752/anti-patte rns-of-social-housing-in-latin-america

Sanchez Gallegos P (2015) Mercado de Suelo Informal y Politicas de Habiat Urbano en la Ciudad de Guayaquil. FLACSO

Sanchez Gallegos P (2017) La ciudad desde abajo vs. la ciudad desde arriba. Contradicciones entre la logica de la necesidad y la logica del mercado en la produccion de la ciudad popular. Guayaquil ecologico. Memorias Del Congreso de Estudios de La Ciudad. CVITIC 2017. Economia Urbana y Gobernanza, 40-69. Cuenca: Casa Editora

SENPLADES (2013) Good Living National Plan 2013 2017. Summarized version. Resumen Plan Nacional Buen Vivir - Español, p. 130. Retrieved from http:// www.buenvivir.gob.ec/

Serra-Llobet A, Hermida MA (2017) Opportunities for green infrastructure under Ecuador's new legal framework. Landsc Urban Plan 159:1-4. https://doi.org/10.1016/j.landurbplan.2016.02.004

Shannon K (2017) Landscape Architecture as Necessity. In: Foundation LA, ed. The Landscape Declaration. A call to action for the twenty-first century (pp. 49-53). https://doi.org/10.1080/18626033.2017.1301421

Shannon K (2020) Silver linings for re-urbanisation in the post-covid-19 Era. My Liveable City, 19-20
Shebell E, Moser S (2019) Planning for the Buen Vivir: Socialism, decentralisation and urbanisation in rural Ecuador. Int Dev Plan Rev 41 (4):473-494. https://doi.org/10.3828/idpr.2019.16

Swyngedouw E (1997) Power, nature, and the city. The conquest of water and the political ecology of urbanization in Guayaquil, Ecuador: 1880-1990. Environ Plan A 29:311-332

Twilley RR, Monroy-Rivera VH, Espinoza RS, Armijos M, Solorzano L (2001) The Gulf of Guayaquil and the Guayas River Estuary, Ecuador. In: Seeliger U, Kjerfve B, eds. Coastal Marine Ecosystems of Latin America (Vol. 144, pp. 245-263). https://doi.org/10.1007/978-3-662-04482-7

Universo E (2020) Cinco intervenciones en Socio Vivienda. El Universo. https:// www.eluniverso.com/guayaquil/2020/02/12/nota/7735938/mas-500policias-intervienen-viviendas-socio-vivienda-2/

Vandegrift R, Thomas DC, Roy BA, Levy M (2017) The extent of recent mining concessions in Ecuador. https://ecuadorendangered.com/research/repor ts/RIC-Mapping-Report-v1.0-20171105-eng.pdf

Vásquez A, Giannotti E, Galdámez E, Velásquez P, Devoto C (2019) Green infrastructure planning to tackle climate change in Latin American cities. Urban Climates Latin America. https://doi.org/10.1007/978-3-319-97013$4 \_13$

Villalba-Eguiluz CU, Etxano I (2017) Buen Vivir vs development (II): the limits of (Neo-)extractivism. Ecol Econ 138:1-11. https://doi.org/10.1016/j.ecole con.2017.03.010

Whittemore ME (2011) The problem of enforcing nature's rigths under ecuador's constitution: why the 2008 environmental amendsments have no bite. Pacific Rim Law Policy J Assoc 20(3):659-691

Wilson EO (2016) Half-Earth: Our Planet's Fight for Life. Liveright Publishing Corporation, New York

\section{Publisher's Note}

Springer Nature remains neutral with regard to jurisdictional claims in published maps and institutional affiliations.

\section{Submit your manuscript to a SpringerOpen ${ }^{\circ}$ journal and benefit from:}

- Convenient online submission

- Rigorous peer review

- Open access: articles freely available online

- High visibility within the field

- Retaining the copyright to your article

Submit your next manuscript at $\boldsymbol{\nabla}$ springeropen.com 